\title{
IAMJ
}

INTERNATIONAL

AYURVEDIC

MEDICAL JOURNAL

\section{A CONCEPTUAL STUDY OF KSHARA KARMA}

$\underline{\text { Neha Chelak }}^{1}, \underline{\text { Balendra Singh }}^{2}$, Uttam Nirmalkar $^{3}, \underline{\text { Avinash Markam }}^{4}$

${ }^{1}$ MS Scholar, P.G. Department of Shalya Tantra, GAC Raipur C.G, India

${ }^{2}$ Reader \& HOD, P.G Department of Shalya tantra GAC Raipur C.G, India

${ }^{3}$ Lecturer, P.G. Department of Shalya Tantra, GAC Raipur C.G, India

${ }^{4}$ Lecturer, P.G. Department of Shalya Tantra, GAC Raipur C.G, India

Corresponding Author: nehachelak8214@gmail.com

https://doi.org/10.46607/iamj3109072021

(Published Online: July 2021)

Open Access

(C) International Ayurvedic Medical Journal, India 2021

Article Received: 01/07//2021 - Peer Reviewed: 04/07/2021 - Accepted for Publication: 05/07/2021

Check for updates

\section{ABSTRACT}

Kshara is a sarcastic alkaline in nature obtained from the ashes of Ayurvedic medicinal plants, animals, Minerals. Kshara used in India from the ancient period for the management of different diseases and disorders. It is a milder procedure compared to thermal cautery. Acharya Sushruta is the pioneer of Kshara Karma, as he introduced Kshara in one of the specific Chapters. Kshara Vidhi Adhyaya. Kshara is considered superior among Shastra Anushastra because it does the functions like excision, cutting \& scraping.

Keywords: Adhyaya, Anushastra, Kshara,

\section{INTRODUCTION}

Kshara is formed by the amalgamation of many plant drugs, it mitigates. The Tridosha being white. Kshara Karma is useful as a substitute for surgical instruments because they can be used safely on patients. who is fear of surgery! Acharya Charaka has men- tioned eighteen parts of herbal drugs which can be used in medicinal purpose Kshara is one among them kshara karma comes under the scope of Shalya Tantra while Acharya Charaka has considered it as one of the three types of treatment is Shastra Pranidhana in 
Harita Samhita Kshara Karma is included in the Eight important types of treatment when the Kshara administered by an ignorant physician can harm the body like Agni, Shastra or even leads to death itself. Acharya Dalhana the commentator of Sushruta Samhita explained the word Ksharana as one which Mobilized \& removes the deformed flash, skin etc. or which removes the vitiated Doshas from their Location. Acharya Chakrapani has described the method of preparation of Kshara. Acharya Yadavji has described a separate chapter of Kshara Kalpana. Kshara Therapy not only minimizes complications but also reduces recurrence of the disease. Kshara can reduce the chances of post-surgical infections due to its alkaline nature. Kshara has the topmost place in all surgical \&para surgical measures.

\section{CLASSIFICATION OF KSHARA -}

On basis of application -

1. Pratisaraniya Kshara (external applications)

2. Paniya Kshara (oral administration)

\section{ACHARYA 'VAGBHATT' CLASSIFICATION}

Bahya (external) Parimarjana \& Antaha (Internal) Parimarjana based on concentration/potency - it is based on the strength or concentration of Kshara to achieve different depths of burning at the site. The PratisaraniyaKshara has been further sub-classified into 3types.

1. Mridu (Mild)

2. Madhyama (Moderate)

3. Tikshana (Strong)

Based on origin -

1. Vanaspatija (Medical Plant) ex - Apamarga Kshara, Yava Kshara

2. Pranija (Animal) ex - Shankha (Coral)

3. Khanija (Mineral) ex - Tankan (Borax)

PRATISARNIYA KSHARA- Applying, Kshara externally

\section{Method of Preparation -}

- Collection of a drug like Apamarga, Palash, Ya$v a$ each with their root, stem, branches, leaves \& fruits i.e. (Panchanga) of the drug.

- Drying the plant in the air.

- Burning till complete convert into Ash.

- 6 parts of water are put into one part of Ash.

- Stir well Kept for overnight.

- Filtered through cloth 21 times.

- Kept for boiling in low flame.

- $1 / 10^{\text {th }}$ part of Prakshepaka Dravyas like Danti, Dravanti, Citraka, Langli, Pravala etc. are added $\&$ boiled in low flame till semi-solid Consistency.

INDICATION - Arshas (Internal haemorrhoids), Bhagandara (fistula in Ano), Arbuda (Tumours), Dustavrana (Ulcers), NadiVrana (Sinus) Charma Keela (warts), Tilakaalaka (None elevated mole), Baahya Vidradi (external abscess) Visha (Disease produced due to poisons). Kitibha (Lichen Planus), Mandal (Psoriasis), Kilas (Leucoderma), Shwitra, Nyacha (Naevi), Vyang (Angiona), Vidradhi (abscess), Krimi (Worm Infestation), Mashak (warts), Bahya Vidradhi (external abscess), mukharoga (disease of mouth), Upjivha (Ranula), Adhijivha (Epiglottitis), Upkush (pyorrhea), Danta Vaidarbha (gingivitis).

PANIYAKSHARA - Internal administration of Kshara in the form of Kshara Jala.

INDICATION- GaraVisha (artificial poison), Vatashalesma Grahni Gulma (Malabsorption syndrome\& Inflammation), Udara (abdomen disease), Agni Maandya (Weak digestive fire), Ashmari (Urinary calculi) Abyantara Vidradhi (Internal abscess), Visuchika (Cholera), Alaska (Meteorism), Vilambika (Distention \& Indigestion), Visha (Disease due to poison) Krimi (Worm Infestation), Arsha (Haemorrhoid), Ajirna (Indigestion), Arochaka (Anorexia). 
Table 1: Kshara karma according to various roga -

\begin{tabular}{|c|c|c|}
\hline Disease & Susruta & Charak \\
\hline Ashmari(calculus) & $\begin{array}{l}\text { Til, Palash, Apamarga } \\
\text { Kshara, (Paniya) }\end{array}$ & - \\
\hline Arbuda (neoplasm) & Kshara (Pratisarniya) & - \\
\hline Nadivrana (sinus) & $\begin{array}{l}\text { Kshar Sutra Prayoga } \\
\text { (Pratisarniya) }\end{array}$ & - \\
\hline Dustavrana (infected wound) & Kshara (mushka, Palash) & - \\
\hline Shwitra (leucoderma) & Ksharataila (pratisarniya) & Kela kshara \\
\hline Mandal Kustha (psoriasis) & & $\begin{array}{l}\text { Kshar Palash (Pratisarniya) Kela, Patala, } \\
\text { Nichul (Jalveta)etc. }\end{array}$ \\
\hline Mashak (warts) & Kshara (Pratisarniya) & - \\
\hline Kshudra roga (minor disease) & $\begin{array}{l}\text { Paddari (Rhagades)- } \\
\text { Yavkshar } \\
\text { Aajgallika (Eruption in } \\
\text { children) -yavkshar, Saj- } \\
\text { jikshar(Pratisarana) }\end{array}$ & - \\
\hline Mukha roga (disease of mouth) & $\begin{array}{l}\text { Danta Vaidarbha- Kshara } \\
\text { (Pratisarniya) } \\
\text { Upjivha, adhijivha. - } \\
\text { pratisarana by kshara } \\
\text { Kaphaostharoga (Inflam- } \\
\text { mation of lips) - } \\
\text { Dvikshara pratisarana }\end{array}$ & - \\
\hline Arsha (Haemorrhoids) & Kshara & - \\
\hline Rakta Pitta (bleeding disorder) & - & $\begin{array}{l}\text { Kamalnaal Kshara (in kaphaanubandhgra- } \\
\text { thitayuktarakta) }\end{array}$ \\
\hline Bhagandara (fistula) & - & Kshara Sutra \{Pratisarniya Kshara\} \\
\hline Udarroga (abdominal disease) & - & $\begin{array}{l}\text { 1.Vayu- Parshavashoola (intercoastal neu- } \\
\text { ralgia) - Bilva Ksharataila Pan (Paniya } \\
\text { Kshar) } \\
\text { 2. Kapha-Kshara }\end{array}$ \\
\hline Grahaniroga - & - & Aam mala - Yavakshar \\
\hline Grahani, Shotha, Arsha & - & Kutajakshara, Palash Kshara (Paniya) \\
\hline $\begin{array}{l}\text { Grahani, Gulma, Pandu, Hridyaroga, Uda- } \\
\text { varta Shoola }\end{array}$ & - & Bhallatak Kshara (Paniya) \\
\hline Grahani & - & $\begin{array}{l}\text { Durlabhaha Kshara increase Grahani Kala } \\
\text { Bala, also stimulate the normal function of } \\
\text { Grahani }\end{array}$ \\
\hline $\begin{array}{l}\text { Anaha (Abdomen Distention), Atisara (Diar- } \\
\text { rhea), Hridyagraha (Valvular heart disease), } \\
\text { Shotha (Inflammation), Prameha (Diabetes), } \\
\text { Pleeha roga (Disease of the spleen)-- }\end{array}$ & - & Trifladi Kshara, (Paniya) Haridra Kshara. \\
\hline Gulma & - & Yavkshara \\
\hline $\begin{array}{l}\text { Rakta Gulma (Haematol Metra, Abdominal } \\
\text { Tumour, Ovarian Cysts, Ovarian Fibroma, } \\
\text { Pseudo Pregnancy }\end{array}$ & - & Palash Kshara (Paniya) \\
\hline
\end{tabular}




\section{DISCUSSION}

Kshara is useful \& very effective in control \& cure various diseases. In the case of pratisarniya Kshara Acharya Sushruta Considered that Kshara Sutra which is a type of Pratisarniya is best in the treatment of Nadivrana. we also see that Bhagandara is also successfully treated by KsharaSutra. The application of Bahya \& Abhyantara Kshara is used in the treatment of Arsha. In the case of Paniya Kshara, Kshara is helping to break the Sharkara of Ashmari.In the case of momentum come out from the abdomen (Meda Vridhi) Kshara Bhasma is used for sprinkling during excision. Sheetala dusting of Vanyopal bhasma in Yoga Ratnakar to prevent any secondary infection. In the case of Dusta wound (Infected wound) Kshara oil is used for cleaning the wound.so, we see that Kshara karma is superior to Shastra Karma because Kshara having the benefits. Of Chedana (Excision), Bhedana (Incision), Lekhana (Scraping), Shodhana (Cleaning), Ropana (Healing) properties.

\section{CONCLUSION}

The patient should require admitting to the hospital for surgery. There is no need for hospitalization for the patient. Another complication of surgery is heavy bleeding. because of the heavy bleeding patient could have a risk of shock\& then can lead to death. but in Kshara Karma, it has properties to stop bleeding \& Kshara have Natural Ingredients so, there is no chance of any harmful effect in the body so that the Kshara Karma is superior, to the Shastr a\& Anushastra Karma.

\section{REFERENCES}

1. Chindarkar V.pritam Dr. A review- kshara karma therapy. www.ijpo.in inter. j. pharma 02 vol.2/issue 2/March-Apr-2020 2582-4708

2. Meghana Dr\& Bharadhwaj Anjali Dr understanding of kshara karma \& its application in shalya tantra www.wjpmr.com world journal of pharmaceutical \& medical research.

3. Sushruta Samhita English Translation Murthy. K. R. Srikantha prof chaukhambha orientalia Varanasi Ed 2012, vol 1, page no 63
4. Charak samhita Dr Bramha nand Tripathi. Dr ganga sahaye pandey chaukhambha subharti prakashana Varanasi Ed 2019 part 1, page no -38, 250

5. Dr Pritam V. Chindarkar A review on kshara karma therapy. asso. prof. dravyaguna department matoshri asarbai darabe Ayurved college Nasik (Maharashtra) India vol 2/issue 2/ mae-apr 2020 inter. j. pharma02

6. Chakradutta Shri jagdishwar Prasad Tripathi, Shri Bahadur Shankar Shastri chaukhambha Sanskrit series Varanasi Ed -5 /page no -90

7. Shusruta Samhita Kaviraj Ambikadutta Shastri chaukhambha sanskrit sansthana Varanasi vol-1 reprint 2016

\section{Source of Support: Nil \\ Conflict of Interest: None Declared}

How to cite this URL: Neha Chelak et al: A Conceptual Study Of Kshara Karma. International Ayurvedic Medical Journal \{online\} 2021 \{cited July 2021\} Available from: http://www.iamj.in/posts/images/upload/1517_1520.pdf 